\title{
Dünden Bugüne Tutkallı Tabakalı Ahşap Yapı Elemanların İncelenmesi ve Yapılarda Taşıyıcı Olarak Kullanılması Üzerine Öneriler
}

\author{
Sinan KAYAKIRAN ${ }^{1}$, Emre KISHALI ${ }^{2 *}$ \\ ORCID 1: 0000-0001-9672-1491 \\ ORCID 2: 0000-0002-1740-5042 \\ ${ }^{1}$ Kocaeli Üniversitesi, Mimarlık ve Tasarım Fakültesi, Mimarlık Bölümü, 41300, Kocaeli, Türkiye. \\ ${ }^{2}$ Kocaeli Üniversitesi, Mimarlık ve Tasarım Fakültesi, Mimarlık Bölümü, 41300, Kocaeli, Türkiye. \\ *e-mail:emre.kishali@kocaeli.edu.tr
}

\section{Öz}

Uluslararası yapı üretiminde son yıllarda çok miktarda kullanılmakta olan "tutkallı tabakalı ahşap yapı elemanları ile oluşturulan taşıyıcı sistemler" in geçmiş yıllarda Türkiye'de hemen hemen hiç tanınmamış olması yakın zamanda bu sisteme karşı merak ve ilgiyi ortaya çıkarmıştır. Günümüzde ise orman endüstrisinin geliştiği ülkeler kadar olmasa da ülkemizde bu yapı malzemeleri ile yapılmış örneklere rastlamaktayız. Ahşap malzemesinin bünyece değişimini sağlayan çeşitli tekniklerin uygulanmasına paralel olarak konstrüksiyon imkanları da genişlemiştir. Ülkemizde üretilen yapısal ahşap açısından yapılacak bir karşılaştırmada, bilhassa tutkallı tabakalı ahşabın henüz tam anlamı ile bir gelişme göstermediği dolayısıyla konstrüksiyon kuruluşlarında da halen geleneksel yapı sistemlerinin devam ettiği söylenebilir. Bu bağlamda, tutkallı tabakalı ahşap yapı elemanlarının ulusal ve uluslararası literatür tarama çalışması yapılmıştır. Makalede ahşap elemanlarla yapılan büyük açıkıkların geçildiği kesitler hakkında genel bilgi, kullanılan tutkallar hakkında bilgi ve tutkal cinsleri, tutkallı tabakalı ahşap yapı elemanlarında kullanılan ahşabın seçimi ve tutkallama yöntemi, birleşim ve ek yerlerinin oluşturma kuralları, ülkemizde ve uluslararası alanda bu yapı elemanlarının üretimlerinde kullanılan standartlar, bu elemanların yangın ve deprem anında göstermiş olduğu mukavemet tepkileri incelenmiştir. Tutkallı tabakalı ahşap özellikleri, üretimi ve kullanım alanları üzerine elde edilmiş bulgular sentezlenerek, Türkiye'deki kullanım olanakları üzerine incelemeler yapılmıs ve öneriler getirilmiştir.

Anahter Kelimeler: Tutkallı tabakalı ahşap, yapı elemanı, Türkiye, ahşap malzeme

\section{The Investigation of the Glued Laminated Timber Elements from Past to Today and The Suggestions for the Use as Load-bearing in the Structures}

\begin{abstract}
Due to not being recognized the structural systems constructed with glued laminated timber elements in Turkey which are used in the international building production frequently, revealed the curiosity and interests towards this system recently. Today, the examples, not as much as the ones built in the countries where the timber industry is developed, constructed with these structural materials are observed in Turkey. Today construction
\end{abstract}

Atıf: Kayakıran, S., Kishalı, E. (2019). Dünden Bugüne Tutkallı Tabakalı Ahşap Yapı Elemanların İncelenmesi ve Yapılarda Taşıyıcı Olarak Kullanılması Üzerine Öneriler. Mimarlık Bilimleri ve Uygulamaları Dergisi (MBUD), 4 (1), 34-50.

DOI: $10.30785 / \mathrm{mbud} .450537$ 
opportunities are developed together with the development of the implementation to the techniques on the timber materials providing the transformation of the structure. Comparing the structural timber produced in our country, it can be noticed that especially the glued laminated timber is not developed properly, therefore traditional structural systems are followed in the construction companies. In this context, state of art on glued laminated timber elements are analysed in the national and international resources. In this article, the general information on the cross-sections of structural timber having wide spans; the glues used in the sector and its types; the choice of timber for the glued laminated timber and gluing process; the principles for the connection and addition of timber elements; the standards used in the production of structural timber in the country and in the international environment; the strength against the fire and the earthquake of these structural elements are analysed. The opportunities of using glued laminated timber elements in Turkey and suggestions for it are presented via synthesizing the findings on the properties, production and, use of these materials.

Keywords: Glued laminated timber, structural elements, Turkey, timber material

\section{Giriş}

Tutkallı tabakalı ahşap yapı elemanları masif tabakalarının basınç altında çeşitli tutkallar kullanarak yapıştırılmasıyla meydana gelmiştir. Yapımındaki amacı, ebat olarak tabii malzemenin elde edilen maksimum boyutunun üzerine çıkmak ve israfı önlemektir. Tabaka düzenlemesi ile homojen ve izotrop bir sistem elde etmek ve presleme ile çeşitli formlara imkân veren bükülebilir bir malzeme, dolayısıyla forme edilmiş konstrüktif bir sistem geliştirmek, mikro organizmalara ve ateşe de yüksek dayanım gösteren tutkallanmış düz ve karmaşık kesitli ahşaplar üretmektir. Böylece geniş açıklıklar geçilebilmektedir (Şekil 1) (Eriç, 1972).

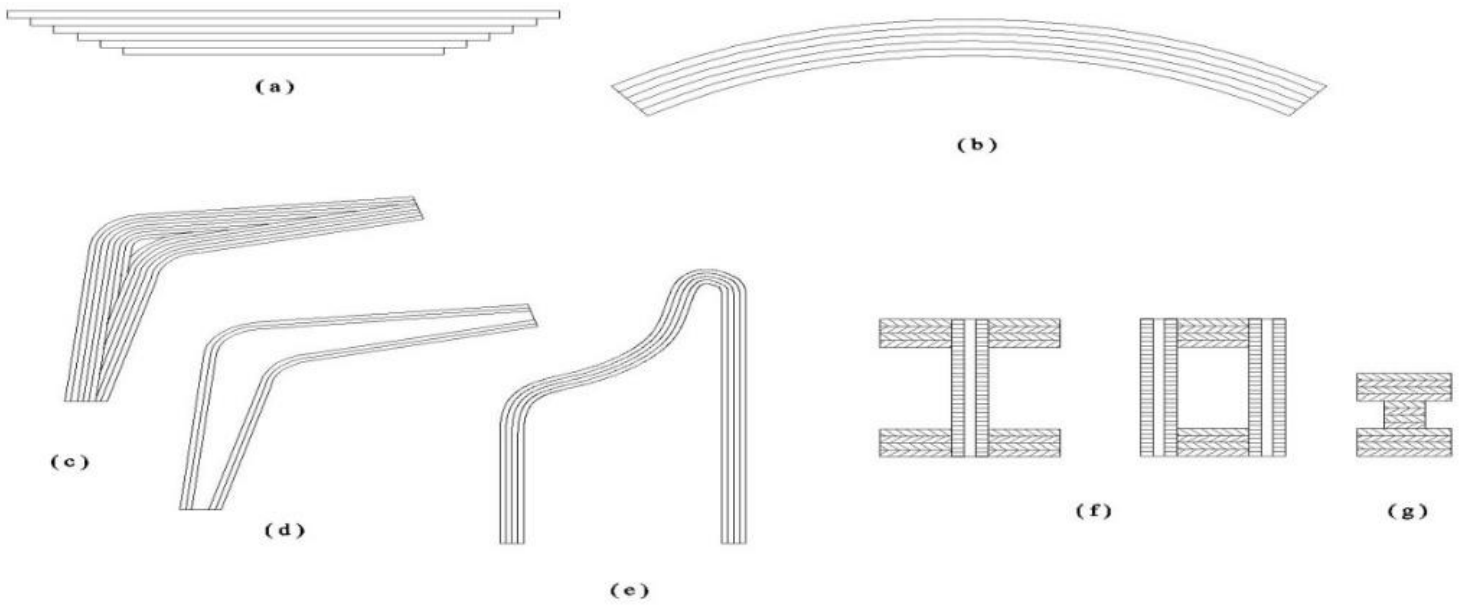

Şekil 1. Tutkallı Tabakalı Ahşap Kesit Tipleri, Dietz, G.H.'den tekrar düzenlenmiştir.

Zaman içinde mimari isteklerin değişmesine, yeni yapılarda geniş açıklıklara ihtiyaç duyulmasına ve teknoloji ile farklı kesitler kullanılarak inşaatlar yapılmasına çeşitli faktörler etkili olmuştur. Bunlardan biri de ahşap malzemelerin seçimi ve yapı sektöründeki endüstriyel gelişmedir. Bu nedenle; özellikle ekonomik nedenlerle yapılarda kullanılması gittikçe zor olan ahşap malzeme, günümüz teknik imkânları ile homojen ve izotrop bir malzeme olarak geliştirilmiştir.

Böylece, ölçü bakımından yapıda kullanılmaya elverişli olmayan ahşap veya değerli diğer ahşaplardan en fazla yaralanma imkânları getiren, fabrikasyon yönü de olan, ekonomik amaçlı ve yapıdaki doğal ahşaptan daha geniş olanaklara sahip olan geliştirilmiş ahşap malzemeler kullanılmaya başlamıştır. Bu arada ahşabın doğal halindeki deformasyonunu gidermek, yanmazlığını sağlamak ve mikro organizmalara karşı dayanımını arttırmak için de koruma teknikleri üzerinde araştırmalar geliştirilmiştir. Ayrıca ahşabın sözü edilen heterojen ve anizotrop yapılarının yüksek kaliteye ulaşması sağlanmıştır. Bu gelişmelere örnekler ise Şekil 2'de sunulmuştur.

Tarih içinde tabakalı ahşabın serüveni ve büyük açıklıkların geçildiği formların incelenmesi ise sistemin sürekliliği ve sürdürülebilirliği açısından önemlidir. Literatür incelendiğinde Avrupa'da bugünkü modern kontrplak sanayinin başlangıcı 18. yy.'a rastlamaktadır (Erşen, 1975). Koruma bağlamında incelendiğinde, 20. yy.'ın başlarında yapılmış ve rutubetten korunmuş tutkallı ahşap 
yapılara ise bugün dahi rastlanmaktadır. Alman inşaat kalfası olan Hetzer tarafından 1904 senesinde inşa edilmiş bir atölye binası bugün de kullanılmaktadır (Erşen, 1975).

Sivil mimaride, kilise inşaatlarında, köprülerde kendini gösteren tutkalı tabakalı ahşap malzemelerle yapılan yapım teknolojilerinin kullanımı, II. Dünya Savaşıyla birlikte askeriyeye ait yapılarda da yaygın olarak kullanılmıştır. Örnek olarak, 1942'de Minnesota'da 52,7 m açıklıklı kirişlerle uçak hangarı yapısı, 1947 yılında Kuzey Dakota'da bulunan uçak hangarı yapısı, 46,8 m açıklık geçen tutkallı tabakalanmış ahşap kemer kirişlerle inşa edilmiştir (Tokyay, 1998). 1940'lı yılların ortalarından itibaren suya dayanıklı sentetik reçineli yapıştııııların kullanılmaya başlanması, tutkallı tabakalanmış ahşabın köprülerde ve diğer strüktürlerde kullanılmasına olanak sağlamıştır (Şekil 3).

ABD'de, 1980 'li ve 1990 'lı yıllarda, tutkallı tabakalı ahşap malzemelerle yapılan yapım teknolojilerinin kullanıldığı köprü yapımı çok yaygınlaşmıştır. Birçok araç yolu köprüsü tutkallı tabakalı hazırlanmış ahşap malzemelerle yapılan yapım teknolojileri kullanılarak yenilenmiştir. Bunlara örnek; mühendislik alanında en iddialı olanlardan biri de yapımı 1968'de tamamlanan Güney Dakota'nın yakınında 3 seviyeli, 47 m açıklık geçen kemer kirişli, 8 m genişlikli, 58 m uzunlukta bir araç köprüsüdür. Ayrıca; Açılışı 1990 yılında yapılan, ABD Michigan'da bulunan Eagle River Köprüsü'de (12×50 m) geniş otoyol köprüleri için yakın geçmişe ait oldukça önemli bir örnektir (Şekil 4) (Tokyay, 1998).

Türkiye'de tutkallı tabakalı ahşap ile inşa edilen yapılardaki gelişmeler yenidir ve ahşabın rasyonel kullanılması konusunun üzerinde de yeterince durulmadığı görülmektedir. Bu nedenle henüz ülkemiz için önemli potansiyele sahip bu yapı malzemesi bu araştırma makalesinde konu edilmiştir. Çalışmanın birincil amacı, mimari üretimde kullanılan ahşap yapı malzemesinin kullanım olanaklarını geçmişten günümüze kadar derlemek ve baskın betonarme üretimine karşı tutkallı tabakalı ahşap elemanların özelliklerini belirtmektir. Konu üzerine çalışmak ve araştırma yapmak isteyen uzmanlara bu konu ile ilgili yapılmış çalışmalar derlenmiştir. Bu bağlamda, tutkallı tabakalı ahşap yapı elemanlarının tanımı, genel bilgiler, üretim tekniği ve standartlar sunularak yapı elemanlarında yangın ve deprem performansını incelenmiştir. Böylece, tutkallı tabakalı ahşap yapı elemanları kullanılan sistemlerin diğer sistemlere göre avantajları ortaya konulmuş ve tutkallı tabakalı ahşap yapıların bugünkü durumu ve Türkiye'de gelişme imkânları hakkında öneriler sunulmuştur.
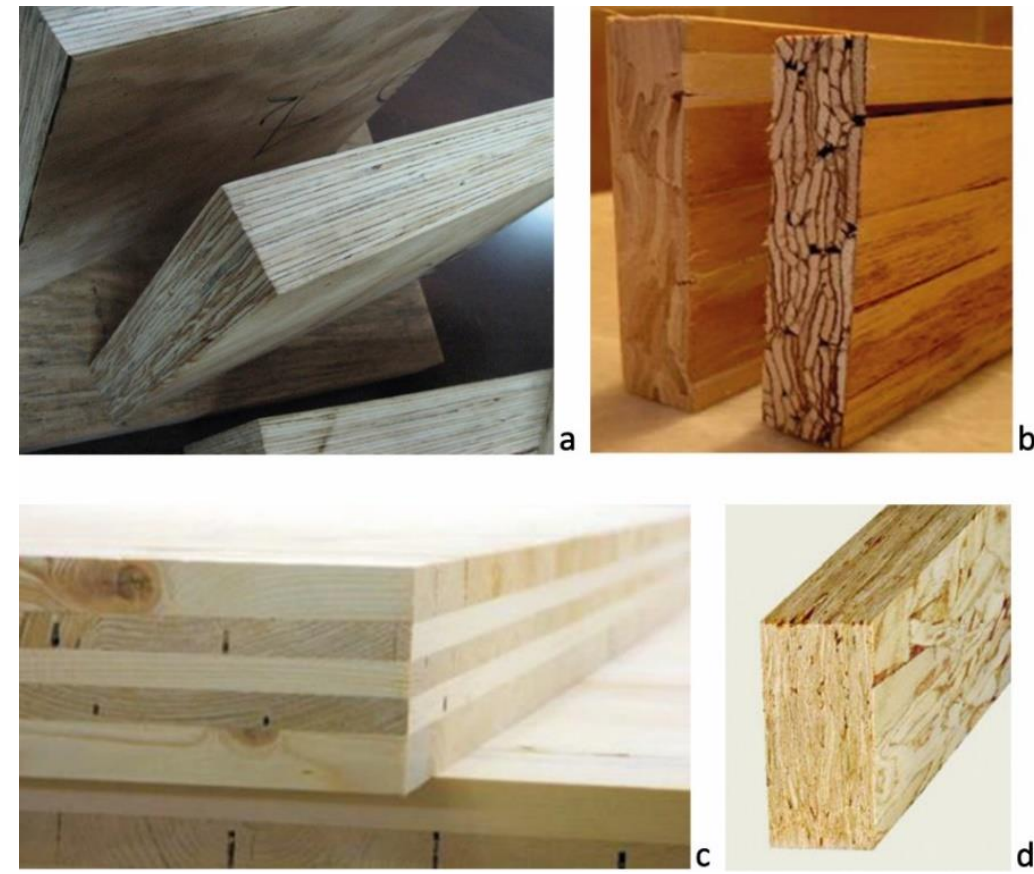

Şekil 2. Tutkalı tabakalı ahşap yapı elemanlarındaki son gelişmeler: (a) LVL- Lamine Kaplama Kereste (Laminated Veneer Lumber) (URL- 1), (b) PSL- Paralel Şerit Kereste (Parallel Strand Lumber) (Çavuş, 2008), (c) CLT- Çapraz Lamine Ahşap (Cross Laminated Timber) (URL -2) ve (d) LSL - Tabakalı Şerit Kereste(Laminated Strand Lumber) (URL-3).

Araştırmada, tutkallı tabakalı ahşap yapı elemanlarının ulusal ve uluslararası literatür tarama çalışması yapılmıştır. Bu çalışmada ise ahşap elemanlarla yapılan büyük açıklıkların geçildiği kesitler 
hakkında genel bilgi, kullanılan tutkallar hakkında bilgi ve tutkal cinsleri, tutkallı tabakalı ahşap yapı elemanlarında kullanılan ahşabın seçimi ve tutkallama yöntemi, birleşim ve ek yerlerinin oluşturma kuralları, tutkallı tabakalı ahşap yapı elemanlarında ülkemizde ve uluslararası üretimleri kullanılan standartlar, tutkallı tabakalı ahşap yapı elemanlarının yangın ve deprem anında göstermiş olduğu mukavemet tepkileri incelenmiştir. Bu sorunlar ışığında, tutkallı tabakalı ahşap üretimi ve kullanımı üzerine elde edilmiş veriler sentezlenerek, Türkiye'deki kullanım olanakları üzerine çalışılmış ve çok boyutlu öneriler getirilmiştir.

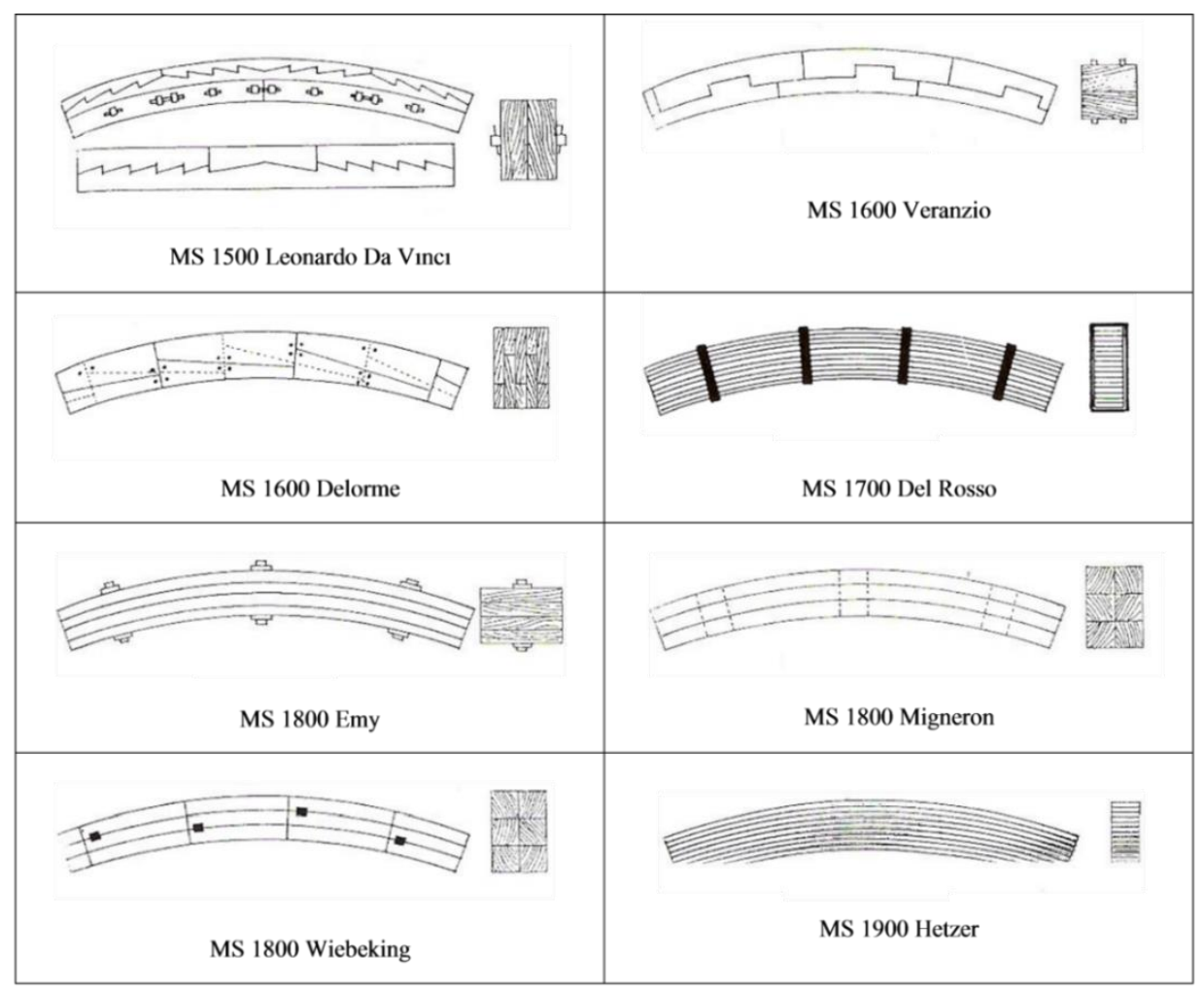

Şekil 3. Tarih içinde tabakalı ahşabın serüveni (Tokyay, 1988).

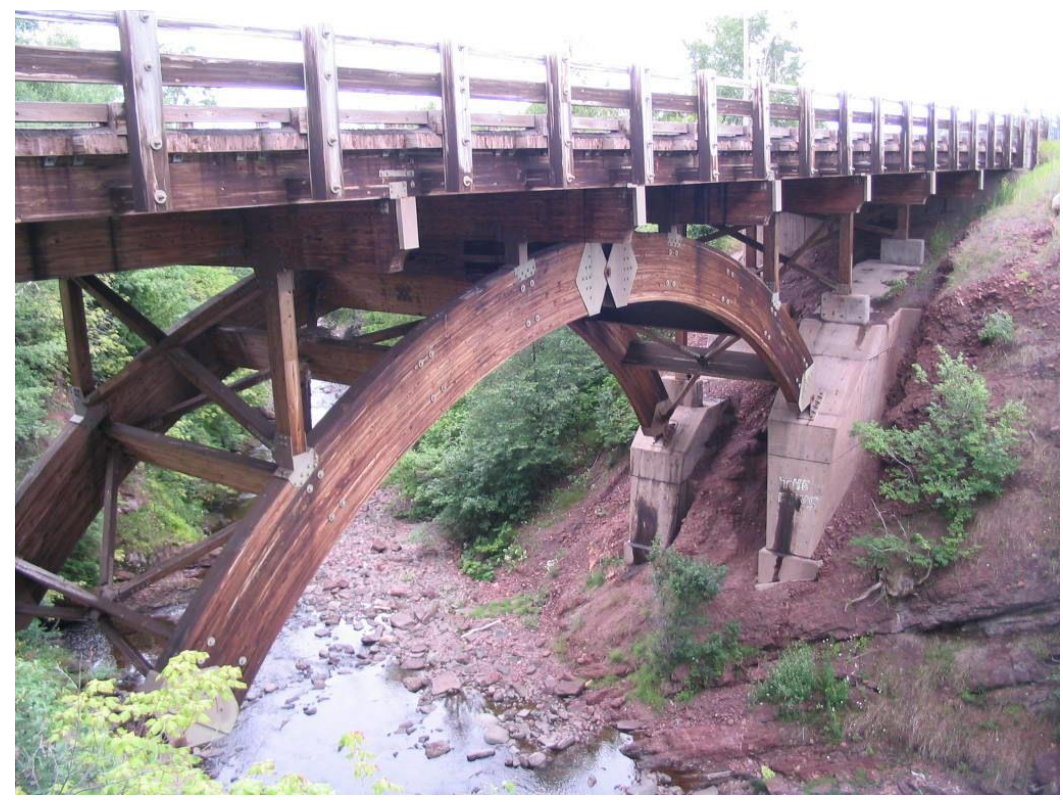

Şekil 4. Eagle River Köprüsü, Michigan (12 m x 50m) Açılış Yılı 1990 (URL-4).

\subsection{Tutkallı Tabakalı Ahşap Yapı Elemanlarının Üretimi}

Tutkallı tabakalı ahşap yapı elemanlarının üretimi konusu zaman içinde, bu konuda üretim yapan ahşap yapı elemanı üreticilerine, yapılış yılları tarihi itibarıyla ahşabın ve ahşap yapıların üretimlerinin 
de değişebildiğini ve sürdürülebilir yeniliklere paralel olarak gelişebildiğini açıkça göstermiştir. Zaman içinde değişmeyen aslında tutkallı tabakalı ahşap yapı elemanının ahşap yapılarda kullanılma isteğidir. Ortak akıl kullanan tasarımcı veya yapı sahibi; ahşap yapı intiyaçlarını gideren eylemlerinde tutkallı tabakalı ahşap yapı elemanları üretimini geliştirirken düşünceleri ve tercihlerini genelde şu noktaya göre odaklamışlardır. Yeni teknoloji büyük ahşap yapılar da aynı kaynaktan temin edilen ahşaptan yapılabiliyorsa, doğadan temin edilen yapı tomruğu ile üretilen ürünlerin her türden kalitesi, her alanda kullanılabilir diyerek, tutkallı tabakalı ahşap yapı elemanları üretimini tutkal türleri ve tutkallama teknolojilerine paralel olarak geliştirmişlerdir.

\subsubsection{Tutkal hakkında genel bilgi ve tutkallı tabakalı ahşap yapı elemanlarında kullanılan tutkal türleri}

Yapıştırıcı maddelerdeki yapıştırma yeteneği genel anlamda adhezyon ve kohezyon olarak bilinir. Adhezyon, yapıştırııının yabancı maddeye yapışması, kohezyon ise kendi moleküllerinin birbirine yapışmasıdır. Aslında her ikisi de moleküllerin birbirini tatbik ettikleri çekme kuvvetlerinin karşılıklı tesirinden ibarettir. Adhezyon kuvvetinin doğabilmesi ancak moleküllerin birbirine yeteri derecede yakın olmasıyla gerçekleşmektedir. Bu yakınlı̆ı̆n oluşması için aradaki mesafenin ölçüsü, bir milimetrenin on milyonda üçünden az olmamalıdır (Duman, 1964).

Bu sebepledir ki pratikte 2 cismi doğrudan doğruya birbirine yapıştırmak mümkün olmaz ve aralarına, tatbiki sırasında sıvı olup sonradan katılaşan bir başka madde koymak gerekir. Işste bu madde, tutkal diye tanımlanır. Çoğu tutkallar yapışma olayı sırasında meydana gelen bir takım fiziksel olaylar ve kimyasal reaksiyonlar sonucu, ilk önce jelatine benzer bir özellikte bir madde haline gelir, sonra da katılaşırlar. Tutkalların bazılarında sıvı halden jel hale geçiş sadece suyun alınması ve soğuması ile olur. Uluslararası literatüre bakıldığında geçmiş yıllarda üretilmiş olan ve/veya halen üretilen tutkallı tabakalı ahşap yapı elemanlarının üretiminde, bazılarının sıklıkla kullanıldı̆ı tutkal türleri üzerine aşağıdaki gibi bir sınıflandırma yapılmaktadır (Duman, 1964).

- Tabii Tutkallar (Genelde taşıyıcı olmayan Tutkallı Tabakalı Ahşap yapı elemanlarında kullanılmaktadır)

- Hayvani Tutkallar. (Glutin Tutkalları, Kan Albümini Tutkalları, Kazein Tutkalları.)

- Bitkisel Olan Tutkallar (Nişasta Tutkalları, Soya Tutkalları)

- Nebati Tutkallar. (Kola Tutkalları, Dekstrin Tutkalları)

- Suni Tutkallar (Sentetik Tutkallar) (Genelde taşıyıcı olan tutkallı tabakalı ahşap yapı elemanlarında kullanılmaktadır)

- Termoplastik Tutkallar

- Duroplastik Tutkallar (Üre-Formaldehit, Melamin Formaldehit, Fenol-Formaldehit RezorsinFornıaldehit) (Duman, 1964).

Ahşap ve ahşaptan üretilmiş bir yapı malzemesinin diğer yapı malzemeleri türlerine göre tutkallama işleminde seçilmesi gereken tutkal cinsi ve yapıştırma yöntemi Şekil 5'de gösterilmiştir.

\subsubsection{Tutkallı tabakalı ahşap yapı elemanlarında kullanılan ahşabın seçimi}

Tutkallı ahşap yapılarda da özel haller hariç, normal olarak, çam sınıfı ahşap kullanılır. Umumiyetle reçinesi bol olanların kullanılmasından sakınılmalıdır. Çünkü fazla reçine ahşabın ayarlanabilir rutubet derecesini olumsuz etkilemektedir. Normal olarak Çevre ve Şehircilik Bakanlığının Yüksek Fen Kurulu Genel İnşaat şartnamesi içerisinde bulunan Yapılarda Ahşap Teknik Şartnamelerinde tariflenen 1. ve 2. sınıf kereste tüm tutkallı tabakalı ahşap yapı elemanlarında kullanılır. Ancak, iç mimari isteklerinin hâkim olduğu bazı özel hâllerde ahşap kalitesinin 1. sınıf olması ve rengine de özen gösterilmesi mecburiyeti gerekmektedir. Avrupa'da özel haller dışında çam kullanılır. Genellikle (\%95 fichte) kızılçam kullanılır. Avrupa'da ve memleketimiz de ahşap 3 sınıfa ayrıldığı halde, Amerika'da 6 sınıfa ayrılmıştır. Tutkallı ahşap yapılarda kullanılanları ise I, II, III ve IV. kalite olanlarıdır (Erşen, 1975).

\subsubsection{Tutkallı tabakalı ahşap yapı elemanlarında rutubet ayarı, emprenye ve üretim aşamaları}

Ahşap higroskopik (su emici) bir malzeme olarak kendi rutubet miktarını bulunduğu yerin rutubet 
miktarı ile dengelemeye çalışır. Rutubet miktarındaki değişmeler ahşapta rötre, şişmelere yol açar (Erşen, 1975). Rötre veya şişmenin fazla olmaması için tutkallanacak ahşabın kullanılacağı yerdeki rutubet miktarına uygun hale getirilmesi gerekmektedir.

Yapıda kullanılmaya hazır hale getirilen tutkallı tabakalı ahşabın bünyesinde bulunan nem oranı ile kullanılacağı yerdeki ortam rutubeti arasında fark olmamalıdır. Aksi bir durum, ahşapta rötre veya şişmenin fazla olmasına, dolayısıyla tutkal derzlerinde ek gerilmeler oluşmasına sebep olur. Bu gerilmeler de ahşapta çatlamaya sebep olur. Bunun için ahşabın rutubet miktarının sonradan yerleştirildiği yere göre ayarlanması ve tutkallanmadan önce kontrol edilmesi şarttır (Erşen, 1975). Rutubet ayarı sonrası emprenye yapılmalıdır.

Emprenye işlemi ahşap malzemenin bünyesinde oluşabilecek çürüme ve böcek tahribatı ile yanma, bozulmayı önlemek ve ömrünü uzatmak amacıyla yayımlanmış standartlara göre kimyasal maddelerin ahşaba nüfus ettirilmesidir (Şener, 1999).

\begin{tabular}{|c|c|c|c|}
\hline 1. Maknene & 2. Mahene & Tutkal Cinsi & Yapuştma Metodu \\
\hline \multirow{5}{*}{ 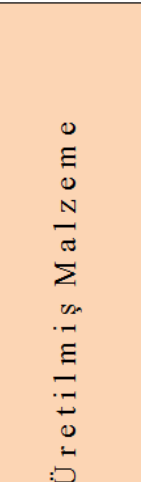 } & $\begin{array}{c}\text { Ahșap Kaplama } \\
\text { Sert Ağaç Birleşimleri }\end{array}$ & $\begin{array}{c}\text { Üre Formaldehit } \\
\text { Polivinil Asetat } \\
\text { Hayvansal Tutkal }\end{array}$ & Soğuk Tatbikat \\
\hline & İnce Ahşap Kaplama & Üre Formaldehit & Sicak Tatbikat \\
\hline & Plastik İnce Kaplama & Üre Formaldehit & $\begin{array}{c}50^{\circ} \mathrm{C} \text { 'nın Üstünde } \\
\text { Basınçlı Sıcak Tatbikat }\end{array}$ \\
\hline & $\begin{array}{l}\text { Kağıt İle Takviyeli } \\
\text { PVC Kaplama }\end{array}$ & Polivinil Asetat & $\begin{array}{c}\text { Püskürtme ve Merdane ile } \\
\text { Tatbikat }\end{array}$ \\
\hline & PVC Karolar & $\begin{array}{l}\text { Normal Polivinil Klorür } \\
\text { Yapıştıncısı,Bitüm }\end{array}$ & .. \\
\hline \multirow{2}{*}{$\begin{array}{l}= \\
\pi \\
\pm \\
0 \\
\pi \\
\pi \\
=\end{array}$} & Asbest & $\begin{array}{l}\text { Hayvansal Tutkal } \\
\text { Resonsinol Reçinası }\end{array}$ & Sicak Tatbikat \\
\hline & Metal & $\begin{array}{c}\text { Epoksi Reçinası } \\
\text { Kauçuk Esaslı Tutkal }\end{array}$ & $\begin{array}{c}\text { Püskürtme ve Merdane ile } \\
\text { Tatbikat }\end{array}$ \\
\hline \multirow{3}{*}{$\begin{array}{l}0 \\
> \\
0 \\
\mathbb{3} \\
\pm \\
\Sigma\end{array}$} & Linolyum & $\begin{array}{c}\text { Üre Formaldehit } \\
\text { Polivinil Asetat } \\
\text { Bitüm }\end{array}$ & $\begin{array}{c}\text { Sıcak Tatbikat } \\
\text { (Basınçlı İyi Netice Alınır) }\end{array}$ \\
\hline & Catı Keçesi & $\begin{array}{c}\text { Bitüm } \\
\text { Kauçuk Esaslı Tutkal }\end{array}$ & .. \\
\hline & $\begin{array}{c}\text { Polistiren Tabaka veya } \\
\text { Karolar }\end{array}$ & Polivinil Asetat'ın Ōzel Tipleri & Soğuk Tatbikat \\
\hline
\end{tabular}

Şekil 5. Malzemeye göre tutkal cinsleri ve yapıştırma metotları, Eriç’ten tekrar düzenlenmiştir (Eriç, 1985).

Tutkallı tabakalı ahşap elemanların emprenyesinde, iki yöntem uygulanmaktadır. Birinci yöntem, tutkallı tabakalı ahşap elemanı oluşturan tahtaların tutkal ile birleştirilmeden önce emprenye edilmesidir. İkinci yöntem ise, bitmiş ürünün basit olarak tüm yüzeylerinde yapılan işlem ile emprenye edilmesidir. Her iki yöntemde de "Emprenyeyi isteyen yapı sahibi ve/veya yapı tasarımcısının talebine uygun renkte, solvent bazlı emprenye sıvısı (asgari $100 \mathrm{gr} / \mathrm{m}^{2}$ ) ile emprenye işlemi ahşap malzemeden oluşan yapı elemanın üzerine uygulanır." (Mutlubaş, 1999). Emprenye işlemine dair görüntüler Şekil 6'da sunulmuştur.

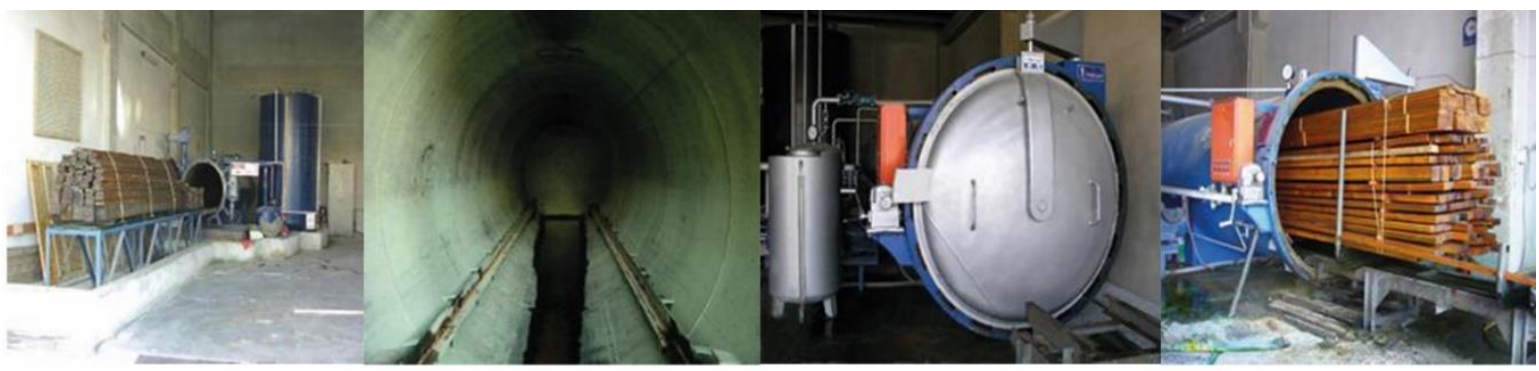


Şekil 6. Emprenye sürecine dair görseller (Sağlam, 2009).

Ahşap malzemeye uygulanan emprenye maddeleri koruyuculuk özelliği sağlamasının yanı sıra yapıştırıcı maddeyle uyum sağlaması da yapışma için çok önemlidir. Basınç metodu ile emprenye edilmiş ağaç malzemelerde tutkalın yapışma direncini azalttığı bilinmektedir. Emprenye madde seçimi ve yöntemi bu yüzden önemlidir. Daha yüksek yapışma direnci değerleri daha kısa süreli daldırma yöntemi ile emprenye edilmiş ağaç malzemelerin yapıştırılmasında meydana geldiği gözlemlenmiştir. (Yörür vd., 2010)

Tutkallama işlemi aşağıdaki sıra ile

- Ahşabın rutubet miktarının tayini

- Tabii ve suni kurutma

- Tutkallanacak yüzeylerin hazırlanması

- Tutkalın hazırlanması

- Tutkalın yerine sürülmesi

- Basınç tatbiki

- Son yüzey düzeltmesi

- Tamamlama nakil ve montaj

- Tamamlama: ambalaj, istif ve yükleme

○ Nakil ve montaj: Boşaltma, ön montaj ve montaj şeklinde yapıımalıdır (Erşen, 1975) (Şekil 7).

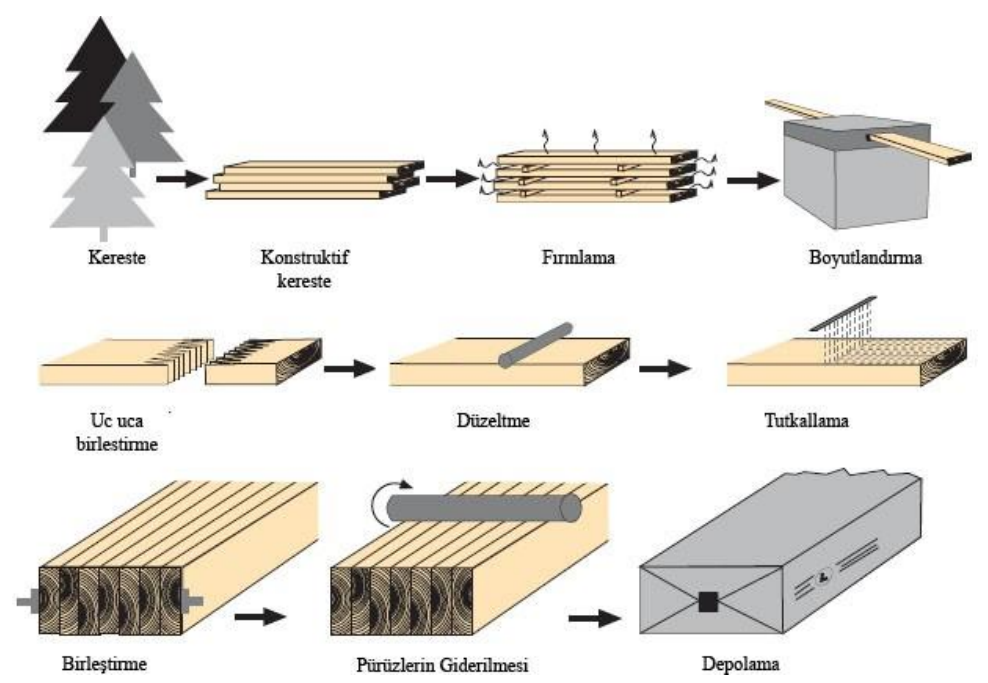

Şekil 7. Tutkallama işlem şeması (Sağlam, 2009).

\subsubsection{Tutkallı tabakalı ahşap yapı elemanlarında ek ve birleşim yerlerinin oluşturulması}

Tutkallı tabakalı ahşap yapı elemanları ile oluşturulan ahşap yapılarda ek yerlerinin oluşturulmasının 2 amacı bulunmaktadır. Bunlardan ilki, taşıyıcı sistem elemanlarının boyunu uzatmak, diğeri de kesitlerini gereği kadar büyütebilmektedir. Tutkallı olan birleşimlerin diğerlerine göre özelliği, birleşimin yüzeyler boyunca, sürekli olmasıdır. Bu nedenledir ki diğer elemanlar ile yapılan birleşimler esnek olmasına karşın tutkal ile yapılan birleşimler çok rijittir. Kullanılan ağaç malzemenin fire oranını azaltmak ve kusurlarından arındırmak için tutkallı tabakalı ahşap yapı elemanları oluşturan katmanlarda en ve boy birleştirme yapılması zorunluluğu vardır (Şenay, 1996) (Şekil 8, Şekil9).
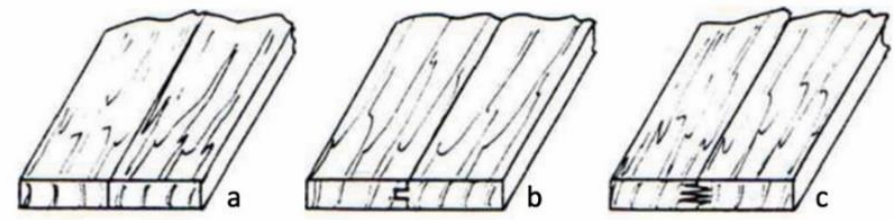

Şekil 8. En birleştirme: (a) Düz birleştirme, (b) Dişli birleştirme (c) Kama dişli (incelen kurtağzı) birleştirme (Şenay, 1996) 


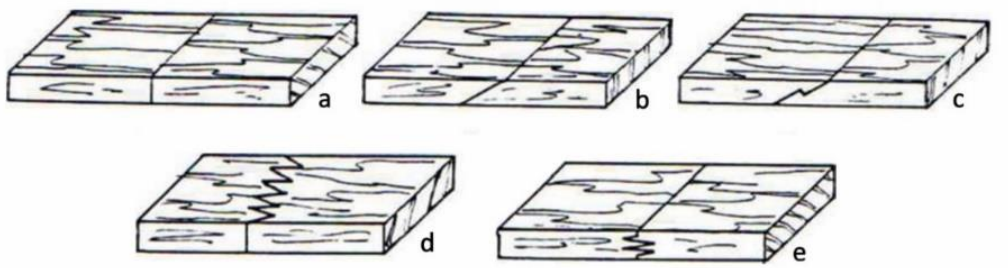

Şekil 9. Boy birleştirme: (a) Düz birleştirme, (b) Pahlı birleştirme, (c) Pahlı kademeli birleştirme, (d) Dikey kama dişli (incelen kurtağzı) ve (e) Düşey kama dişli (incelen kurtağzı) (Şenay, 1996)

\subsection{Tutkallı Tabakalı Ahşap Yapı Elemanlarında Kullanılan Standartlar}

Tutkallı tabakalı ahşap yapı elemanları ile oluşturulan ahşap taşıyıcı sistem, büyük açıklık gerektiren hemen her türlü mimari tasarımın inşasında yaygın olarak kullanılabilir. Sistemin yaygın kullanımı, çeşitli ülkelerin bu amaçla birtakım standartlar oluşturmasını gerekli kılmıştır. Örneğin; Kanada'da "Kanada Ahşap Konseyi" (CWC) 1959, ABD'de "Amerikan Ahşap Yapı Enstitüsü" (AITC) 1952 ve Avrupa'da 1973'te başlatılan ve yürürlüğe sokulan "Eurocode5" (EC5) standardı bunlardan birkaç tanesidir. Tüm bunların yanı sıra, Türkiye'de de ahşap yapı standartları oluşturulmuştur ve kapsamlıdır (URL-5). Ancak; tutkallı tabakalı ahşap ile yapı inşaatına yönelik rehber olacak standartlar ya da yönetmelikler yurtdışı örneklerine kıyasla literatürde daha azdır. Mevcut yürürlükte olanların en eskisi ise TSE 647 (Ahşap yapıların hesap ve yapım kuralları)'nin yayımlandığı 1979 yılından kalma standartlardır. Ülkemizde ise strüktürel ahşapla ilgili Türk Standartları Enstitüsü (TSE)'nce yayımlanan, yayımlandığı yıl ve sonrası itibariyle sadece tutkallı tabakalı ahşap yapı elemanlar ile ilgili olan ve standart içeriğinde de üretimi, birleşimi tanımlanmış imalatlarda kullanılan bazı standartlar aşağıda sunulmuştur (Altunkaya, 2007).

- TS EN 386 Tutkallanmış lâmine kereste- Performans özellikleri ve asgarî imalat şartları (Kabul Tarihi: 07.04.1999),

- $\quad$ TS EN 387 Tutkallı lamine ahşap- Geniş kama dişli birleştirmeler- Performans ve asgari üretim özellikleri (Kabul Tarihi: 24.04.2003),

- $\quad$ TS EN 390 Yapıştırılmış lamine kereste- Boyutlar- Kabul edilebilir sapmalar (Kabul Tarihi: 09.04.1999),

- $\quad$ TS EN 391 Tutkallanmış lâmine kereste-Tutkal hatlarından tabakaların ayrılması deneyi (Kabul Tarihi: 09.03.2006),

- TS EN 392 Yapıştırılmış lamine kereste- Yapıştırılmış tabakaların makaslama deneyi (Kabul Tarihi: 09.04.1999),

- $\quad$ TS EN 1194 Yapı keresteleri- Yapıştırılmış lamine kereste- Mukavemet sınıfları ve karakteristik değerlerin tayini (Kabul Tarihi: 13.03.2002),

- $\quad$ TS EN 14080 Ahşap yapılar- Tutkallı lamine kereste- Özellikler (Kabul Tarihi: 18.12.2013),

- $\quad$ TS 5497 EN 408 Ahşap yapılar- Yapı kerestesi ve tutkallanmış lamine kereste - Bazı fiziksel ve mekanik özelliklerinin tayini (Kabul Tarihi: 18.09.1997) (Altunkaya, 2007).

Ayrıca hem Avrupa'da hem de Amerika'da bu sisteme ait çalışmalar artarak yoğunlaşmaktadır ve tutkallı tabakalı ahşap yapı elemanları ile oluşturulan yapıları üreten fabrikaların sayısı da artmaktadır, özellikle Amerika, Almanya'da konuyla ilgili standartların, sistemin tanıtıcı yayınların bulunduğu kitaplar basılmıştır. Bu yayınlar, standartların gelişmelerini olumlu yolda etkilemiştir. Bu yayınlara, 1966 'da ilk baskısının yapıldığı "Ahşap Yapı El Kitabı (Timber Construction Manual)" adlı kitap örnek verilebilir (AITC, 2012).

\subsection{Tutkallı Tabakalı Ahşap Yapı Elemanlarının Yangın ve Deprem Mukavemetleri}

Güvenilir malzeme ve esaslı teknik bilgi geçmişten günümüze tüm ahşaplı yapıların ortak eylem planıdır. Günümüz tasarımlarını yürüten ekiplerin eylem planlarına, gelişen teknolojik imkânlar doğrultusunda kullanma derecelerine göre ilaveler gelmiştir. Bu sebeple, doğadan temin edilen 
tomruktan üretilen tutkallı tabakalı ahşap yapı elemanları gibi modern ahşap yapı elemanlarının yangın ve deprem anındaki mukavemetleri de gelişen teknolojilerle birlikte incelenmiştir. Denenmiş hesaplama modelleri ve korunma metotları ile kombine edilerek mevcut hesaplamalar geliştirilmiş ve böylelikle ahşap ham maddesinin geleceğin yapı malzemesine dönüştürülmesinde yangın ve deprem mukavemetinin iyileştirilmesinde önemli adımlar atılmıştır (URL-6).

\subsubsection{Tutkallı tabakalı ahşap yapı elemanlarının yangın mukavemeti}

Bilindiği gibi organik bir malzeme olan ahşap yanıcıdır. Yanma olayının gerçekleşmesi için iletilen sıcaklığın kritik dereceye ulaşması gerekmektedir. Bu arada ahşabın kesiti de önemli rol oynamaktadır. Yanma esnasında dış yüzeyden başlayarak çepeçevre kömürleşme başlar. Bu kömür manto, ne kadar kalın olursa yanma olayı için gereken oksijen azalır, ısının içeriye girip kritik dereceye erişmesi de o kadar zorlaşır (Erşen, 1975). Yangın anında tutkallı tabakalı ahşap yapı elemanlarında yanan ahşap yapı elemanının boyutu, yapıştırıldığı ahşabın maksimum boyutuna göre daha büyük olduğundan yanma yüzeyi daha geniştir. Bununla birlikte yanma sonrası oluşan kömür manto da normal kesitteki ahşaba göre, tutkallı ahşapta oluşturulan kesite bağlı olarak daha kalın ve geniştir. Kalınlığın ve genişliğin artması, yangının tutkallı tabakalı ahşap yapı elemanında minimum taşıma gücü kesitine ulaşma süresini uzatmaktadır (Şekil 10). Malzemenin yangına dayanımı açısından; tutkallı tabakalı ahşap yapı elemanlarında kullanılan malzeme ve sistemin yangına dayanımları ile diğer yapı malzemelerin yangına karşı dayanımlarını karşılaştırmalı olarak gösteren grafik Şekil 11'de sunulmuştur (Eriç, 1972).

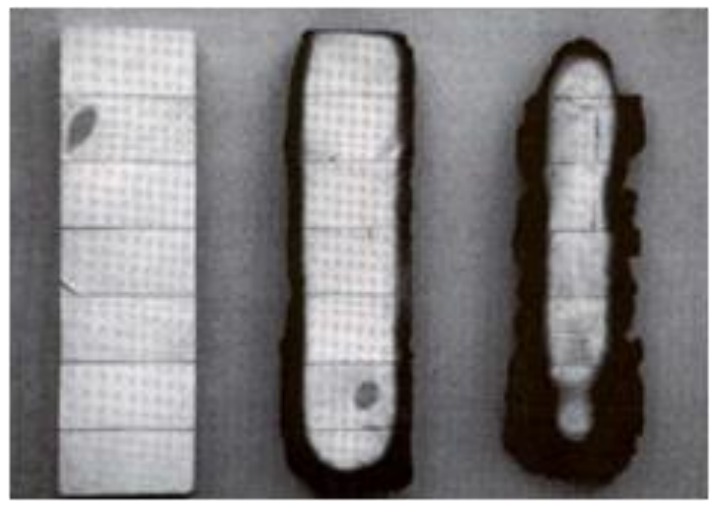

Şekil 10. $90 \mathrm{~mm} \times 315 \mathrm{~mm}$ kesitli bir tutkallı tabakalanmış ahşap elemanın zamana bağlı olarak yangında dayanımı (ortadaki örnek 30dk sonra, sağdaki $60 \mathrm{dk}$ sonraki durumu göstermektedir. (Altunkaya, 2007)

Ahşabın statik hesaba göre aldığı minimum kesit yangın anında minimum 30 dakika (R30) yangın direnci sağlamaktadır. 30 dakikadan sonra, $0.7 \mathrm{~mm} / \mathrm{l}$ dakika kesit azalması olmaktadır. Yani, ilk mimari/statik planlamada, yapı elemanının kesitini baştan artırıp, yangın direncini R30'un üzerinde tutarak R90 dirençlerine ulaşmak mümkündür (Şenay, 1996). Taşıyıcı yapı elemanının ateşe dayanımı, ancak bağlantı elemanları da aynı dayanıma sahip olduğu takdirde sağlanır. Bağlantılar dıştan uygulanırsa, yangına dayanıklı malzemeler ile kaplanması gerekir ki, bu maliyeti artırır. Ahşap içine gizli çelik bağlantılar yapılırsa yangına dayanım, önemli ölçüde artırılmış olur (Kalay, 2006). 


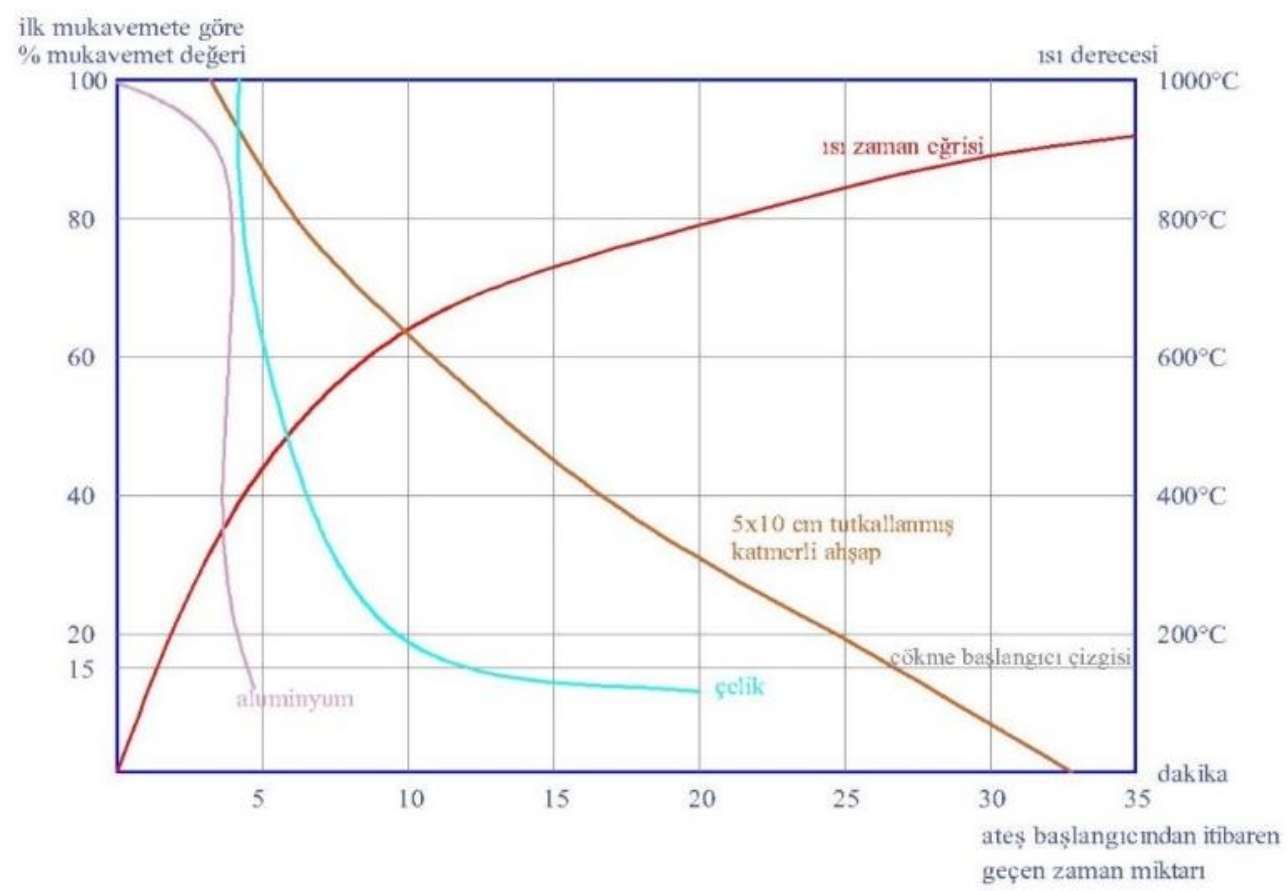

Şekil 11. Tutkallı tabakalı ahşap yapı elemanlarında kullanılan malzeme ve sistemin yangına dayanımlarının diğer yapı malzemeleriyle karşılaştırılması. Eriç'ten tekrar düzenlemiştir (Eriç, 1972).

Bilindiği gibi yangın karşısında tüm ahşap malzemelerde $170^{\circ} \mathrm{C}$ ye kadar kuruma ve kabuk atmaları, $270^{\circ} C^{\prime}$ ye kadar $(C 0, C 02)$ ve buhar çıkışı görülür. Tutuşma sıcaklığı $250-300^{\circ} \mathrm{C}$ 'dir (Eriç, 1983). Yangına karşı kesin güvenlik istenen durumlarda ise ahşabın alev almasını önleyen çeşitli özel emprenye metotları ve boyalar mevcuttur (Erdoğmuş, 1984).

Ayrıca, yapılan bazı çalışmalarda lamine ahşap malzemenin masif ahşaba göre daha düşük yangın dayanımına sahip olduğu bulunmuştur. Bu çalışmalarda kullanılan tutkal ve ahşap kesitleri değişiklik göstermektedir. Özen vd. 3×19 mm kesitli lamine ve masif sarıçam örneklerinde yangından en az etkilenen örneğin doğal ahşap olduğunu bulmuştur (Özen vd. 2001). Bir diğer karşılaştırmalı

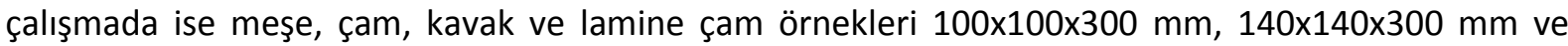
160×160×300 mm büyük kesitli olmak üzere üç farklı ölçüde incelenmiştir. Lamine çamın tutkal cinsi belirtilmemiş fakat masif çamdan daha yanıcı olduğu bulunmuştur (Pehlivan, 2017).

Öte yandan, tutkallı tabakalı ahşap elemanların üretiminde kullanılan tutkallar sayesinde tutkallı tabakalı ahşap ile tutkallı tabakalı ahşap yapı elemanı boyutlarına ulaşabilmiş masif ahşap arasında yangın direnci arasında fark olduğu unutulmamalıdır. Bu sebeple tutkallanmak suretiyle elde edilen tutkallı tabakalı ahşap malzemede kullanılan tutkallar, yangın anında oluşturulan büyük kesitli ahşabın fiziksel ve mekanik özelliklerini etkilemesi açısından önem taşımaktadır. Üretilen tutkallı tabakalı ahşap yapı elemanlarında yüksek teknoloji özelliği gösteren, yangın direnci ve aderans kalitesi yüksek, melamin türevi (MUF) ve resorcinol bazlı (PRF) bağlayıcılar (tutkallar) kullanıldığından oluşturulan yapı elemanının yangın mukavemeti de yüksektir. Bununla birlikte Tutkal bağlayıcı kullanarak oluşturulan Tutkallı tabakalı ahşap yapı elemanının yangın anında fiziksel ve mekanik özelliklerini en mükemmel performansa getirebilmek için, yapı elemanının kullanıldığı yere göre (harici, dâhili, nemli ortam, vb.) bağlayıcı (tutkal) tipi de değişkenlik gösterebilmektedir (Mutlubaş, 1999 s.45; Tokyay, 1998). Bu çalışmalara son yılda Frangi'nin çalışması eklenmiştir. Çapraz lamine ahşaplar için yapmış olduğu çalışmada tutkalların lamine ahşaplardaki yangın davranışını incelemiştir. Bu çalışmaya göre, çapraz lamine ahşaplar masif ahşaplara benzer davranış sergilemişlerdir fakat burada kullanılan tutkalın cinsi göz önünde bulundurulmalıdır. Özellikle, daha kalın ahşap paneller ile üretilen bu yapı elemanlarının yangın dayanımı daha yüksek olmuştur (Frangi vd., 2009). Çapraz lamine ahşap ve glulam gibi son yıllarda üretilen tutkallı tabakalı yapı malzemelerinin yangın dayanımı çalışmalarına bakıldığında, yapıların yangın performansının yüksek olduğu görülmektedir. Su vd. tarafından 2018 'de yapılan yangın deneylerinde, 5 katmanlı 17,5 mm'den oluşan ladin - çam ve köknar cinsi ağaçların poliüretan bağlayıcı tutkal ile elde edilmiş CLT duvar; 32,7 x 45,7 cm kesitli 
kiriş ve 45,7x45,7 cm kesitli poliüretan bağlayıcı uygulayarak elde edilmiş glulam kolonlar ile üretilmiş mekânların (4,53 m x 2,44 m x 2,78 m), alçı panel yalıtım uygulanmış ve uygulanmamış tutkallı ahşap elemanlarda yangın dayanımı incelenmiştir. Buna göre, seçilen bağlayıcı tutkal türü, yangın esnasında CLT duvarlarda oluşan kömürleşmiş katmanların yapı elemanından ayrılması engellenmiştir. Yangın testlerinde oluşturulan yangın düzeneklerinde, 240 ve 247 dakika boyunca yanan yapı elemanları Kanada Ulusal Yapı Şartnamesi 2020'ye uygun sonuçlar vermiştir (Su vd., 2018).

\subsubsection{Tutkallı tabakalı ahşap yapı elemanlarının deprem mukavemeti}

Ülkemizin deprem kuşağında bulunan bir ülke olduğu bilinmektedir. Türkiye gibi topraklarının neredeyse \%95'inin deprem bölgesinde yer aldığı bir ülkede, depreme dayanıklı, hafif, uygulanması ve üretimi kolay olan malzemelerin ve sistemlerin önerilmesi ve araştırılması gerekmektedir. Bu araştırmalar gerek malzeme gerekse taşıyıcı sistem seçimlerini kapsamalıdır. Ahşabın fiziksel, mekanik ve dinamik özelliklerinin yanı sıra kullanım, ekonomik ve estetik değerleri özelleştirilmesi gereken konu başlıkları olarak sınıflandırılabilir.

Malzeme özellikleri bakımından tutkallı tabakalı ahşap yapı elemanları ile oluşturulan yapılarda, yapı elemanlarının hafif ve kesitlerinin ince olması yapı yüklerinde büyük azalmalara sebep olur. Böylece, yapı üzerindeki deprem yükü azalır ve yapının deprem güvenliği artar. Ayrıca; hafifliğinin yanı sıra, şok etkisine dayanıklı ve titreşim emme özelliğine sahip bir yapı malzemesi olması nedeniyle, tutkallı tabakalı ahşap yapı elemanları deprem etkisine karşı dayanıklıdır. Deprem açısından bakıldığında, tutkallı tabakalı ahşap malzemenin bir başka avantajı da şantiye uygulama süreçlerinin kısa olması nedeni ile deprem sonucu ortaya çıkan acil yapı ihtiyacı için uygun yapı malzeme olmasıdır. (Kalay, 2006).

Günümüz Türkiye'sinde tutkalıı tabakalı ahşap yapı elemanlarının kullanımını daha da yaygınlaştırmak için son gelişmelerden biri de 18.03.2018 Tarihli 30364 (Mükerrer) sayılı Resmi Gazetede "Türkiye Bina Deprem Yönetmeliği "başlığı altında yayımlanan son deprem yönetmeliğinde; depremin etkisinde kalan yapısal modellemelerde ve hesaplarda süneklilik düzeyi sınırlı sistemler olarak tutkallı perde ve tutkallı döşeme panel elemanlar konusu da ele alınmıştır (URL-7).

\subsection{Tutkallı Tabakalı Ahşap Yapı Elemanlarının Diğer Sistemlerde Kullanılan Malzemelere Göre Avantajları}

Tutkal kullanmak suretiyle, mukavemeti artırılan ve uç uca eklenerek istenilen uzunlukta ahşap elemanların yapılması, bunları yan yana veya üst üste tutkallamak suretiyle istenilen kesitin elde edilmesi, elemanlara eğri formun verilmesi, vs. sayesinde diğer birleşim elemanları ile yapılan birleşimlere göre, tutkallı tabakalı ahşap yapı elemanlarının avantajları maddeler halinde şöyledir;

- Piyasadan kolaylıkla temin edilebilen normal boy tahta ve kalasların tutkallanması suretiyle, önemli büyüklükte (çerçeve, kabuk, vs.) taşıyıcı sistemler oluşturulur.

- Teknik kurallara uyulursa tutkallı bir yapı elemanının mukavemetinin birleştirildiği parçanın mukavemetinden üstün olduğu ispatlanmıştır (Şekil 12).

- $\quad$ Alt başlı̆ı düz olan kafes kirişlerle dolu gövdeli düz kirişlerde güçlükler çıkaran ters sehim verme problemi tutkallı tabakalı ahşap yapı elemanlarında ek masraf gerekmeden kolayca çözülebilir.

- $\quad$ Üst başlığı eğri olan sistemlerde (parabolik kafes kirişlerde) tutkaldan başka birleşim elemanı kullandığımızda ortaya çıkan sorunlar, tutkallı tabakalı ahşap yapı elemanları kullanıldığında oluşmaz.

- $\quad$ Tutkallı birleşik kesitlerde, kesite gelen yük sonucu oluşan farklı gerilmeleri kesitte farklı tipte ahşap kullanarak ayarlamak, yani ahşaptan ekonomi sağlamak mümkündür.

- $\quad$ Kesit ölçüleri büyük olan ahşap elemanlar, kolaylıkla imal edilip, çevrenin rutubet derecesine göre ayarlanabilir. Bu tipte hazırlanmış elemanlarda, yapının kullanılması halinde oluşacak rötre ve şişme ihmal edilecek kadar azdır.

- Tutkallı tabakalı ahşap yapı elemanlarının çürümeye karşı mukavemeti, diğer birleşim elemanları ile yapılanlara oranla yüksektir.

- Tutkallı tabakalı ahşap yapı elemanlarının gerek boyutsal gerek mekanik özellikleri 
geliştirildiğinden ve büyük ölçülerde üretildiğinden, oluşturulmuş olan tutkallı tabakalı ahşap yapı elemanlarının çevrelerinde meydana gelen, standart ahşaplarda oluşacağı kabul edilenden daha kalın ve daha geniş kor tabakası yangının içeriye girmesini yavaşlatır. Taşıyıcı sistem yıkılmadan bir müddet yük taşımaya devam eder. Bu sebepledir ki; endüstriyel ahşap ile oluşturulan taşıyıcı sistemler (Örneğin CLT sistemler), betonarme veya çelik malzemeli yapımlarla karşılaştırıldığında eşdeğer strüktürel dayanım ve yangın direnci, düşük enerji ile üretilebilme, daha hafif bir temel strüktürü gerektirmesi gibi nedenlerle üstünlük sağlarlar (Güzel ve Yesügey, 2015).

- Kalite bakımından diğer birleşim elemanlarında bile kullanılmayan birçok ahşap, bu sistemde ıslah edilmek suretiyle kullanılabilir.

- Tutkallı birleşimlerin bir diğer avantajı ise yapı elemanı olarak ahşap kabuk örtülü yapıların gelişmesine imkân veren bir sistem olmasıdır (Duman, 1964).

- Yukarıda saydığımız, tutkallı tabakalı ahşap yapı elemanlarının avantajlarının yanı sıra bazı dezavantajları da vardır. Bunların başında iyi malzeme temini, konunun uzmanı teknik eleman, gerekli makina ve teçhizatın bulunduğu büyük bir atölye, kullanılan malzeme miktarı, geniş malzeme stok alanı, montaj ve nakildeki zorluklar vs. sayılabilir.

a)

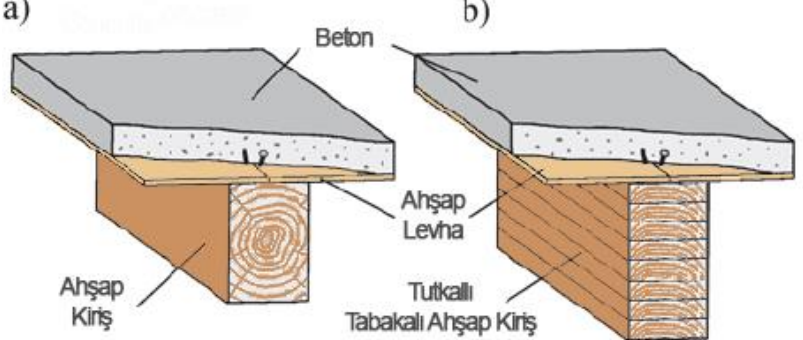

Şekil 12. Tutkalıı bir yapı elemanının (b) Kirişinin (taşıma gücü $=X(+++) t / m 2$ ) mukavemetinin birleştirildiği parçanın (a) Kirişinin (Taşıma gücü $=X \mathrm{t} / \mathrm{m} 2$ ) mukavemetinden üstün olduğunu gösterir şematik çizim Gurkðnys'dan tekrar düzenlemiştir (Gurkðnys, 2005).

\subsection{Tutkallı Tabakalı Ahşap Yapı Elemanları ile İnşa Edilmiş Yurtdışı Yapı Örnekleri}

Tutkallı tabakalı ahşap yapı elemanları ile inşa edilmiş yurtdışı yapı örnekleri sayıca fazladır. Ülkemizde ise yoğun olarak tercih edilen betonarme yapım sistemi ve sektörde büyük bir paya sahip beton üreticilerine rağmen ahşap yapı inşası kendine yer bulmaktadır. Bunlardan Asmaz Ahşap A.Ş tarafından yapılan Sas Otomotiv Ford Otosan Gölcük Ofis Yapısı (URL-8) ve Naswood A.Ş tarafından inşa edilen Avcılar İstanbul Büyükşehir Belediyesi Sosyal Tesisleri (URL-9) örnek olarak gösterilebilir. Zira uluslararası örnekler incelendiğinde bu durumun yeterli olmadığı da ortadadır. Hâkim yapı sistemi ve inşaat malzemesinin yanı sıra Türkiye depremselliği de göz önünde bulundurulursa tutkal tabakalı ahşap sistemler ile inşa edilmiş örneklerin sınırlı kalması gözlemlenen bir durumdur. Bu çalışmada kamusal olarak kullanılan kilise, müze, terminal binası ve köprü yapılarından temsili birer örnek sunulmuştur. Tacoma, Washington, Amerika Birleşik Devletleri (ABD)'nde inşa edilmiş olan LeMay-America's Otomobil Müzesi Amerikalı mimar Alan Grant tarafından 2012 yılında inşa edilmiştir. Her yıl yaklaşık 400.000 kişi ziyaretçi alan müzede toplam 350 otomobil bulunmaktadır (URL-10). Giovanni Rotondo, İtalya'da Renzo Piano tarafından 2004 yılında inşa edilmiş Padre Pio Pilgrimage Kilisesi ise bu malzeme ile inşa edilmiş dini bir yapı örneğidir (URL-11) (Şekil 14). Western Wood firması tarafından, Portland, Oregon, ABD'de 1997'de yapılmış olan 390 vagon kapasiteli toplu terminal binası $635,5 \mathrm{~m}$ uzunluğunda, $48,8 \mathrm{~m}$ genişliğinde ve $25,9 \mathrm{~m}$ yüksekliğindedir (URL-10). Aynı şirket tarafından 2008 yılında Washington'da yapılan Güney Prairie Köprüsü ise kemer açıklıkları 38m; $39 \mathrm{~m}$ ve $35 \mathrm{~m}$ olan 3 kemerden oluşmaktadır (URL-12) (Şekil 14 ve Şekil 15). Literatür incelendiğinde bu sistemle az ve orta katlı konut yapıların inşa edildiği görülmektedir. Ayrıca bu sistemlerde kullanılan malzemeler, Pasif ev, enerji etkin yapı veya sıfıra yakın enerji tüketen yapı projeleri için tercih edilen malzeme seçeneği olarak öne çıkmaktadır. (Güzel ve Karaman, 2015; Güzel ve Yesügey, 2015). Tutkalı Tabakalı Ahşap yapı elemanlarının ofis, okul, dini yapı ve yükseköğretim gibi farklı 
yapılarda kullanıldığı da göze çarpmaktadır. Bu yapılarda özellikle farkıı malzeme ile olan kullanımı da anlatılmaktadır. Bu örneklerin yapım sürecinden sonra özellikle karbon analizleri ve sürdürülebilirlik açısından gelen bilgiler ile mevcut standartlara güncellemeler önerilmektedir. (Exovo BM TRADA, 2017) (Jones, 2018). Son olarak ahşap gökdelenlerin inşaat projeleri ve inşaat çalışmaları devam etmektedir (Şekil 14). Tasarımı etkileyen, yüksek yapı tasarımının malzemesi olarak kerestenin resmi sınıflandırmasına ait çalışmaların uygulanması ahşap malzeme kullanımının yeni sınırlarını göstermektedir (Foster vd., 2018).

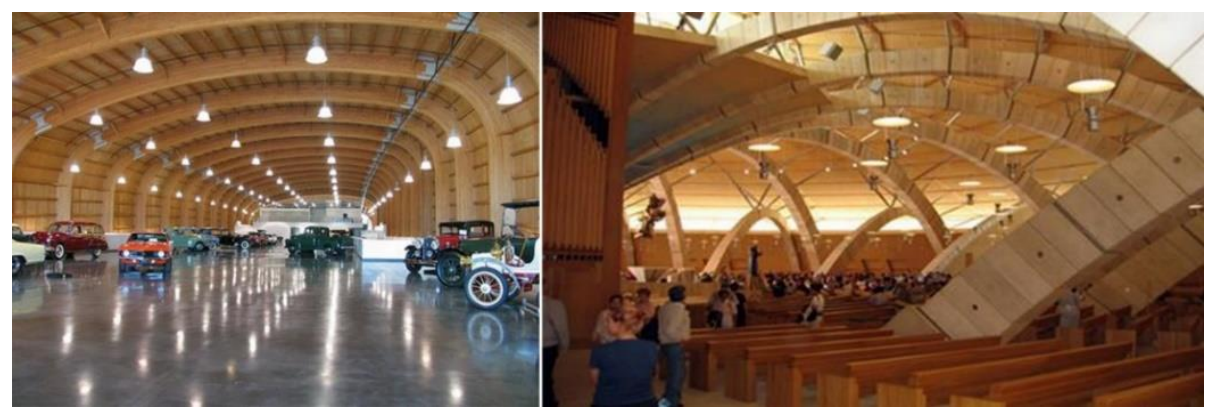

Şekil 13. LeMay - America's Otomobil Müzesi (solda)(URL - 10) ve Padre Pio Pilgrimage Kilisesi (sağda)(URL 11).

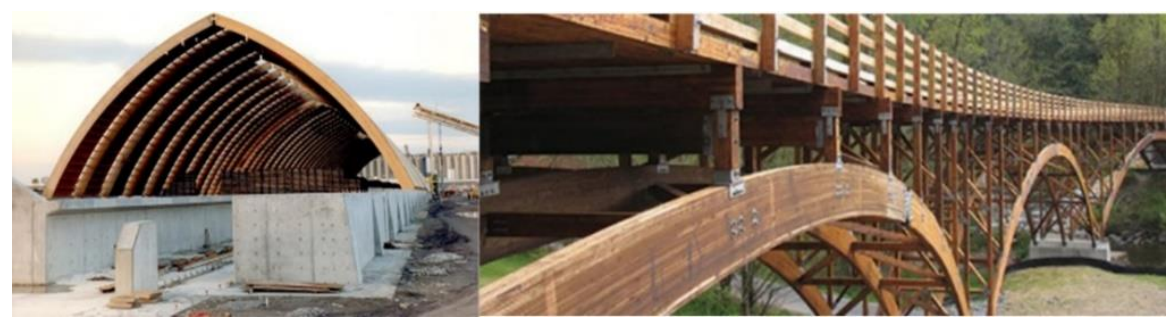

Şekil 14. Portland Toplu terminal binası (solda) (URL-10) ve Güney Prairie Köprüsü (sağda) (URL -12).

Günümüz yüksek yapı tasarımlarına örnek; İngiliz mimar Waugh Thistleton tarafından Londra 'da tasarlanan 121 birim konut kontrplak binası, bugüne kadar yapılmış en büyük ahşap binalardan sadece biri değil, aynı zamanda bugüne kadar yapılmıs en büyük CLT binasıdır. 10 katlı, dıştan, çekirdek duvarlardan zemin katlara ve merdivenlere kadar tamamen CLT'den (Çapraz Lamine Ahşap) yapılmıştır. Eşdeğer büyüklüğüne sahip beton bir binanın beşte biri ağırlığında ve inşaat sırasında şantiyeye yapılan sevkiyat sayısının \% 80 oranında azaltıldığı tespit edilen özelliklerinden bazılarıdır (Şekil 15) (URL-13).

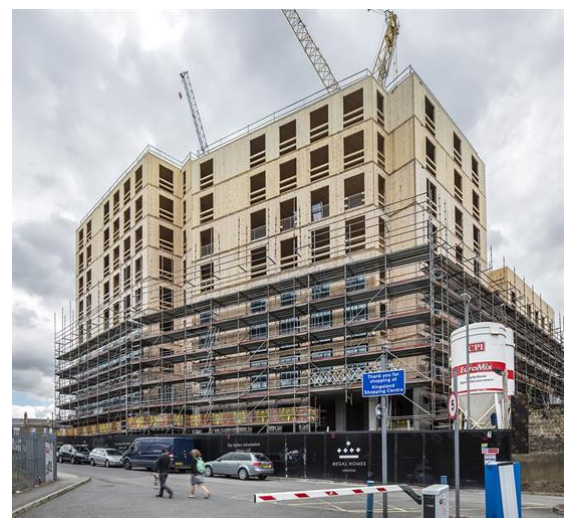

Şekil 15. Doğu Londra'daki çok katlı bir konut bloğu (URL-13)

\section{Sonuç ve Öneriler}

Türkiye'de yapı sektörü ekonominin önemli dallarından biridir. Ülkemizde ekonominin büyümesine paralel olarak, yapı malzemeleri üretimi de özellikle 1960 yıllarından itibaren önemli artışlar göstermiştir. Ancak hızlı nüfus artışımız ile diğer ülkelerdeki kişi başına düşen üretime göre karşılaştırma yaptığımızda üretimin gerek nitelik gerekse nicelik yönünden çok yetersiz olduğu anlaşılmaktadır. Geçmiş dönemlerdeki geleneksel yapı, teknoloji ve yapı malzemeleri bakımından 
yeterliydi. Ancak endüstrileşme ve onun getirdiği yeniliklerin, teknolojinin ülkemizde yeterince ilerlememesi kişi başına düşen üretimin azalmasına, yurt dışında yapılan örnek çalışmaların ülkemizde uygulanmasından çok, bu tür çalışmaların inceleme aşamasında kalmasına, dolayısıyla tutkalı tabakalı ahşap yapı sektöründe yetersiz kalmamıza yol açmıştır (Eriç, 1985).

Günümüzde ise geçmişten farklı bir anlayışla 21. yy. Türkiye ekonomisindeki büyümeye paralel olarak birçok sektörde görüldüğü gibi ahşap yapı sektöründe, özellikle de tutkallı tabakalı ahşap yapı sektöründe de büyüme gözle görülmektedir. Yabancı ülkelerdeki kadar olmasa da tutkallı tabakalı ahşap yapı elemanlarının üretilmesini ve bu yapı elemanları ile ortaya çıkan ahşap yapıların hemen hemen her çeşidini ülkemizde görmekteyiz. Sektörde, yerli üretim konusunda önde gelen firmaları ve sivil toplum örgütü olan, 2000 yılında kurulmuş UAB'de (Ulusal Ahşap Birliği) söz sahibi olarak görmekteyiz.

Bununla birlikte; günümüz Türkiye'sinde her ne kadar üretimi yaygın olarak yapıldığı görülse de yapı sektöründeki gerek istenilen standartlar gerekse nitelik yönünden ülkemizde yetersiz sayılabilecek konulardan biri de bu makalede anlatılan "tutkalı tabakalı ahşap yapı elemanları" nın incelenmesi ve yapılarda taşıyıcı olarak kullanılması konusudur. Gerek teknoloji gerekse sağladığı çoğu kolaylıklar bakımından tutkallı tabakalı ahşap yapı elemanlarının Türkiye'de gelişme imkânları konusundaki öneriler şu şekildedir;

Göz önünde bulundurulması gereken husus, tutkallı tabakalı ahşap yapı elmanı ile oluşturulan sistemin gelişmesinin, bütüncül bir eğitim ve öğretim sisteminin uygulanması ile oluşacağıdır. Bu yüzden, halen eğitim veren, mimarlık ve mühendislik fakültelerinde öğrenim gören, yarının mimar, iç mimar ve mühendis adaylarının okumakta olduğu, ahşap ve ahşap yapılar ile ilgili dersin zorunlu ders olması ve ders içinde bu konuya da yer verilmesi gerekmektedir. Böylece konudan haberdar olan teknik elemanların sayısı çoğalacaktır. Dolayısıyla üniversitelerin lisans seviyesinde okutulan bu konu, konudan haberdar olan üniversite mezunlarını yüksek lisans, doktora, doçentlik, vs. seviyelerde araştırma yapmaya sevk edecektir. Yapılan bu araştırmalar sayesinde elde edilecek bilgiler değerlendirilerek, bu konudan habersiz olan ilgili teknik kişilere, konu hakkında yeterli bilgi alma imkânı verilecektir. Konunun uzman kişiler tarafından ortaya konmasından sonra Çevre ve Şehircilik Bakanlığının Yüksek Fen Kurulu Genel İnşaat Şartnamesi içerisinde bulunan Yapılarda Ahşap Teknik Şartnamelerine (URL-9) ilave ek şartnameler hazırlatarak yayımlatması gerekmektedir. ilgili standart hazırlanırken;

- Türkiye'de mevcut tutkal cinsleri, ormanlarımızın bugünkü durumları ve istatistiki bilgileri ilave ekler halinde güncellenerek yayımlanmalıdır. TSE'nin bu standartlar hazırlanırken uyması gereken bir diğer konusu ise; yurt dışında bu konu ile ilgili standartları; örneğin, DiN 1052 (Ahşap Yapı Malzemesi Avrupa Standartları), AITC 113-65 (Tutkallı Lamine Yapı Çerçevelerinde Boyutlardaki Standartlar), EC5 vs. ulusal inşa koşullarına göre revize etmesi gerekliliği konusudur.

- TSE'nin bu konu hakkında, eskilere ilave olarak çıkaracağı her yeni standart, bu sistemin yaygın olarak uygulanmaya başlanmasında etkili olacaktır.

- Esas teşvik "Devlet" desteğiyle olmalıdır. Devletin bu konudaki gelişme imkânlarının çoğalması ve konunun teoriden pratiğe geçmesine ilişkin radikal kararlar alarak, uygulama safhasına geçmek için merkezi idare ve yerel yönetimler aracılı̆ı ile atılımlar yapması lazımdır. Devlet eliyle yapımı planlanan projelerde bu sistemin kullanılması teşvik edilmelidir.

- $\quad$ Ülkemizde halen faaliyetlerine devam eden, faaliyet konusu dayanışma, katılım ve paylaşım esaslarına dayanan bir sivil toplum örgütü olan, 2000 yılında kurulmuş UAB (Ulusal Ahşap Birliği) derneği de modern bilimin ahşaba verdiği önemi dikkate alarak, Anadolu coğrafyasının getirdiği gereklilikler ve kültürümüzden alınan ilhamla çalışmalar yapmaya devam etmelidir. Ayrıca, ahşabın bir inşaat malzemesi olarak sahip olduğu değerlerin üzerinde durarak bilinçli ahşap tüketimini arttıracak projeleri ortaya çıkaran politikalar üretmeye devam etmelidir. Bu bağlamda girişimleri arttırmak için ahşap yapı ve üretimi üzerine farkındalık çalışmalarını üniversite, kamu kuruluşları, belediyeler ile örnek olarak gerçekleştirmelidir.

- $\quad$ ilave olarak, üniversitelerin adı geçen ilgili bakanlıklara; bu konuda, konunun sağlayacağı yararları ve diğer faydalı özelliklerini belirten resmi bir yazı göndererek girişimde bulunması gerekmektedir. 
- Yarışma ile yapmak kültürünün mimari üretimlerde gelişmesi ve bu yapı malzemesinin de kullanılmasını zorunlu kılacak şartnameler hazırlamak gereklidir. Bu malzemeyi direkt belirleyici tarifler yazarak ulusal yarışmaların açılması ve kazanan projenin de uygulanması malzeme kullanımı açısından teşvik edici olacaktır.

- $\quad$ Kamu kuruluşları, organize sanayi bölgeleri ve özel teşebbüs iş birlikleri ile gerçekleştirilecek yeni üretimler teşvik edilmelidir. Bu üretimler çok disiplinli denetlenebilir, ulusal ya da uluslararası fonlar ile desteklenen AR-GE (araştırma ve geliştirme) merkezleri tarafından genişletilmeli ve geliştirilmelidir. Elde edilen bilgiler, uzmanlara ve konu ile ilgili paydaşlara ücretsiz sunulmalıdır.

Ülkemizdeki ahşap yapı sektörünün gelişimi için yukarıda sayılan tüm bu önerilerin eksikliğine rağmen bilinmedir ki, Uluslararası örneklerde görülen ve uygulanan "tutkallı tabakalı ahşap yapı elemanları "nın yapı sektöründe sağladığı kolaylıklar çoğunluktadır ve ilgili standartları ile bilimsel olarak da ispatlanmıştır. Sağladığı kolaylıkların yanında, tutkallı tabakalı ahşap yapı elemanlarının herkes tarafından kolayca imâl ve monte edilemeyecek bir niteliğe sahip olduğu makalede anlatılan konulardan çıkan önemli bir sonuçtur. Ancak en önemli sonuç; Ülkemizde, Çevre ve Şehircilik Bakanlığının yayımladığı ve gereğinde güncellediği Yüksek Fen Kurulu Genel İnşaat şartnamesi içerisinde tariflenen Yapılarda Ahşap Teknik Şartnameleri içinde tutkallı tabakalı ahşap yapı elemanları üretimi ve birleşimleri konusuyla ilgili hükümlerin yeteri kadar olmayışı, şartnameler öncesinde de TSE'nin mevcut standartlara ilave gereken standartları çıkarmada yetersiz kalması, tutkallı tabakalı ahşap yapı elemanları üretimi ve montaj ile ilgili gerekli teknik eleman yetersizliği, makine ve teçhizatın yetersiz oluşu nedeni ile uygulama alanı az olarak nitelendirilebilecek girişimlerin dışında büyük ölçekte herhangi bir ciddi yatırım ve yatırımcı olmayışıdır. Yukarda önerilenler ilgililerce yerine getirildiği ve paralelinde kamuoyu ile paylaşıldığı takdirde bu sistemin, Türkiye'deki yapı üretiminde gelişmesi ve yerleşmesi mümkün olabilecektir.

\section{Kaynaklar}

AITC (American Institute of Timber Construction) (2012). Timber Construction Manual: Sixth Edition. $10.1002 / 9781118279687$.

Altunkaya.P. (2007). Tutkallı Tabakalanmış Ahşap Strüktür Sistemlerinin Mimaride Kullanım Olanakları. KTÜ Yüksek Lisans Tezi, Trabzon.

Çavuş, V., (2008). Melez Kavak Klonundan (Populus X Euramaricana) Fenol Formaldehit ve Üre Formaldehit Tutkalı Kullanılarak Üretilmiş Paralel Şerit Kerestelerin (PŞK) Bazı Fiziksel ve Mekanik Özellikleri. Kahramanmaraş Sütçü İmam Üniversitesi, Fen Bilimleri Enstitüsü, Yüksek Lisans Tezi, Kahramanmaraş.

Dietz, A.G.H. (1949). Materials of construction: wood, plastics, fabrics. D. Van Nostrand Company.

Duman, N. (1964). Tutkallı Ahşap Yapılar, iTü.

Erdoğmuş, E. (1984). Yapıda Ahşabın Korunması, Yapı koruyucular semineri. Y.E.M.

Eriç, M. (1972). Dünün ve bugünün ahşap ve ahşaptan üretilmiş malzemenin Türkiye şartları içinde yapıda rasyonel kullanılma imkânlarının araştırılması. İstanbul Teknik Üniversitesi. Doktora tezi, İstanbul.

Eriç, M. (1983). Yapılarda Yangının Malzemeye Etkisi. Birinci Yangın Ulusal Kurultayı, Ankara, 293-315.

Eriç, M. (1985). Yapı Teknolojisinin Gelişiminde Malzeme Sorunları, YAPI 60, (say:46).

Erşen, N. (1975). Tutkal Birleşimli Ahşap Taşıııcı Sistemler bugünkü durumları ve gelişme imkânları, iDMMA. Doçentlik tezi, İstanbul.

Exova BM TRADA. (2017). Cross-laminated Timber: Design and Performance, ISBN 1909594636.

Foster, R., Reynolds, T., ve Ramage, M. (2018). What is tall timber? Towards the formal classification of timber as a material of tall building design. World Conference on Timber Engineering 2018, 20- 23 Ağustos, 2018 Seul, Güney Kore.

Frangi, A., Fontana, M., Hugi, E. ve Jübstl, R. (2009). Experimental analysis of cross-laminated timber panels in fire. Fire Safety Journal, 44, 1078-1087. 
Gurkðnys, K., Kvedaras, A. ve Kavaliauskas, S. (2005). Behaviour evaluation of "sleeved" connectors in composite timber-concrete floors. Journal of Civil Engineering and Management, 277 (4), 277-282. 10.1080/13923730.2005.9636358.

Güzel, N. ve Yesügey, S. C. (2015). Çapraz Lamine Ahşap (CLT) Malzeme ile Çok Katlı Ahşap Yapılar. Mimarlık, $382,60-65$.

Güzel, N. ve Karaman Ö. Y. (2015). Sürdürülebilir Bir Alternatif Olarak Çok Katlı Ahşap Yapılar. Ege Mimarlık, 91, 30-35.

Jones, S. (2018). Mass Timber: Design and Research, Oro Editions, ISBN 193962195X

Kalay.E. (2006). Tutkallı Tabakal Ahşap ve Çelik Malzemeli Taşıyıcı Yapı Elemanlarının Form ve Açıklık Kriterleri Açısından İncelenmesi. Dokuz Eylül Üniversitesi Yüksek Lisans Tezi, İzmir.

Mutlubaş, F. (1999). Çağdaş Yapımda Ahşabın Kullanılması, Dokuz Eylül Üniversitesi, Yüksek Lisans Tezi. İzmir.

Özen, R. ve Özçifçi, A. (2001). Emprenyeli Sarıçam (Pinus Sylvestris L.) Odunundan Üretilen Lamine Ağaç Malzemelerin Yanma Özellikleri. Pamukkale Univ Muh Bilim Derg. 7(1): 131-138.

Pehlivan, G. F. (2017), Tarihî Yapılarda Pasif Yangın Önlemlerinin Artırılmasına Yönelik Bir Yöntem Önerisi. Selçuk Üniversitesi, Doktora tezi, Konya.

Sağlam, B.A. (2009). İ.T.Ü. Yüksek Lisans Tezi, İstanbul.

Su, J., Lafrance, P-S., Hoehler, M. ve Bundy M. (2018). Fire Safety Challenges of Tall Wood Buildings -Phase 2: Task 2 \& 3 - Cross Laminated Timber Compartment Fire Tests. National Fire Protection Association. NFPA report: FPRF-2018-01.

Şenay, A. (1996). Lamine Edilmiş Ağaç Malzemenin Teknolojik Özellikleri. İstanbul Üniversitesi, Doktora Tezi. İstanbul

Şener, Y. (1999), Ahşabın Öyküsü, Art Decor, 79, 146-158.

Tokyay, V. (1998) Tutkallı Tabakalı Ahşap Teknolojisi, Yapı, 197. 114.

Yörür, H., Aydemir, D. ve Uysal, B. (2010). Emprenye Edilmiş Ahşap Malzemenin Yapışma Direncini Etkileyen Faktörler. Bartın orman Fakültesi Dergisi, 12 (18), 99 - 106.

URL-1. Engineered Wood Solutions. Erişim Tarihi: 30.07.2018, Laminated Veneer Lumber http://ewsolutions.net/our-products/laminated-veneer-lumber-Ivl/

URL-2. Ulusal Ahşap Birliği. Erişim Tarihi: 30.07.2018, Ahşap Yapı Sistemleri CLT Celalettin Akça celalettin-akca.pdf http://www.ahsap.org/assets/pdfDocs/etkinlik-2/Ahsap-yapi-sistemleri-CLT-

URL-3. Dataholz. Erişim Tarihi: 30.07.2018, Laminated Strand Lumber, https://www.dataholz.eu/en/buildingmaterials/particle-composites/laminated-strand-lumber-Isl.htm

URL-4. Bridge Hunter. Erişim Tarihi: 30.07.2018, Eagle River Bridge, https://bridgehunter.com/mi/keweenaw/eagle-river/

URL-5. Çevre ve Şehircilik Bakanlığı Yüksek Fen Kurulu Genel İnşaat şartnamesi (Yapıda Ahşap Teknik Şartnameleri). Erişim Tarihi: 16.12.2018 http://www.ahsap.org/bilgi/standartlar-ve-sartnameler/

URL-6. Ahşap İle Yapı Doğal, Sürdürülebilir, Güvenilir Egger Ürünleri İle Ahşap Yapılar. Erişim Tarihi:16.12.2018 https://docplayer.biz.tr/3300567-Ahsap-ile-yapi-dogal-surdurulebilir-guvenilir-egger-urunleri-ile-ahsapyapilar-www-egger-com.html

URL-7. İnşaat Mühendisleri Odası. Erişim Tarihi: 30.07.2018, Deprem Etkisi Altında Binaların Tasarımı İçin Esaslar, http://www.imo.org.tr/resimler/dosya_ekler/89227ad223d3b7a_ek.pdf

URL-8. Asmaz Ahşap A.Ş uygulaması Sas Otomotiv Ford Otosan Gölcük Erişim Tarihi:16.12.2018 https://www.asmazahsap.com/uygulamalarimiz/sas-otomotiv-ford-otosan-golcuk/

URL-9. Naswood A.Ş uygulaması Avcılar İstanbul Büyükşehir Belediyesi Sosyal Tesisleri Erişim Tarihi:16.12.2018 http://www.naswood.com.tr/cpanel/galeri.php?proid=1

URL-10. Western Wood Structures. Erişim Tarihi:30.07.2018, America's Car Museum, http://westernwoodstructures.com/index.php/articles/americas-car-museum/ 
URL-11. Architettura di Pietra. Erişim Tarihi: 30.07.2018, Padre Pio Pilgrimage Church, http://www.architetturadipietra.it/wp/?p=2920

URL-12. Foothills Rails to Trails Coalition. Erişim Tarihi: 30.07.2018, Arched Bridge, http://www.piercecountytrails.org/arched-bridge-3/

URL-13. Thistleton, W. Doğu Londra'daki bir konut bloğu. Erişim Tarihi: 16.12.2018, https://www.theb1m.com/video/dalston-lane-the-worlds-largest-timber-building 